\title{
LOS ESPACIOS DE LA AUSENCIA Y LA PÉRDIDA EN LIBRO DEL FRÍO
}

\author{
María PAYERAS GRAU \\ Universitat de les Illes Balears \\ Y no hallé cosa en que poner los ojos \\ que no fuese recuerdo de la muerte. \\ Quevedo
}

A ntonio Gamoneda es un poeta de honda estirpe elegíaca, cuya voz se expresa desde la pérdida. En este sentido, Libro del frío declara a partir del mismo título su raíz, pues del mismo modo que el frío se define en negativo como la ausencia de calor, así el propio poemario instala su discurso en los espacios contiguos de la ausencia y la melancolía, que tienen su proyección simbólica en la evocación de lugares devastados por el tiempo, vaciados de aquello que un día les hizo vertebrar otra realidad, ahora inaccesible. Si la poesía de Gamoneda es, según definición de Miguel Casado, «un diálogo con el tiempo» ${ }^{1}$, Libro del frío es, por parte del autor, la constatación de la llegada a una frontera próxima al límite de ese tiempo. La mirada del poeta se proyecta hacia concretos espacios de la experiencia personal, solo para encontrar en ellos la evidencia de su caducidad.

«Geórgicas» vincula la palabra del poeta al medio rural y la sitúa en el núcleo de la memoria infantil; es, por lo tanto, un bloque poemático que se vincula al origen de la propia existencia y por ello, desde el primer poema, remite al vértigo existencial: «¿qué hago yo delante del abismo?», exclama. Podría decirse que esa pregunta inicial tiene dos especies de réplicas, que clausuran, respectivamente, el primer y el último apartado del libro. La primera réplica relaciona la conciencia de la muerte con la tentación del silencio. La muerte es el espacio propio del silencio en tanto que no puede nombrarse lo desconocido. Al tiempo, la certeza de la propia muerte paraliza la voluntad y cercena la voz. Del sinsentido de la existencia a la insuficiencia de la palabra, «Geórgicas» cierra sobre sí el círculo de la iniciación al vértigo de la experiencia, pero lo hace aferrándose a los vestigios de la memoria personal y a una voz que todavía se afirma como testimonio del yo entre las ruinas del pasado. La segunda réplica a la que me refería es la clausura del libro: «He atravesado las cortinas blancas:/ ya sólo hay luz dentro de mis ojos». Estos versos finales anuncian el ingreso en lo desconocido, asumen como inevitable el fin que se adivina cercano. La palabra poética traza, así, una parábola desde el alfa hasta el omega, erigiéndose a sí misma en baluarte de la vida.

\footnotetext{
${ }^{1}$ M. Casado (1988), «Prólogo», A. Gamoneda, Edad, 9.
} 
En «Geórgicas», la mirada del poeta recorre los lugares familiares, desvelando en cada uno la tensión entre lo telúrico y lo espiritual que repite la lucha de opuestos residenciada en la intimidad del sujeto y que decanta su escritura hacia lo que José Manuel Diego ha descrito como simbiosis «entre la esfera de lo físico y el mundo de las abstracciones» ${ }^{2}$. Entre las «viñas abrasadas» surge la visión de un pasado violento que propaga el temor hasta el presente. Adentrándose en el espesor de la memoria, la conciencia poética observa las precarias supervivencias del pasado en lugares y objetos en los que sobrenadan el dolor y la muerte. El regreso del sujeto a los espacios habitados en un tiempo anterior revela, entre el voluntarioso esfuerzo de la memoria, la conciencia de no pertenecer a ellos y la certeza de que su identidad individual se sustancia en lo que fueron, en todo lo que encerraron, ya fuera bello o monstruoso.

La enigmática figura que se nombra como «El vigilante de la nieve» aglutina los textos que se concentran bajo el mismo título. La voz poética se traslada aquí de la primera a la tercera persona del singular adoptando, simultáneamente, un tono narrativo. Una vez más, el espacio poético vertebra la palabra en el orden simbólico. La nieve es la representación acabada del frío y es el paisaje en torno al cual se modula la experiencia del personaje que lo habita. El sujeto poético, antes definido en singular, se integra ahora en el colectivo «nosotros», que acentúa la soledad como rasgo constitutivo del «vigilante». Es en este aspecto donde la dimensión ontológica del texto adquiere su verdadera proporción, desprendiéndose de adherencias accidentales y apuntando a la condición esencial del ser humano. Cierto que el personaje se corresponde biográficamente con la figura de un amigo prematuramente desaparecido, pero no es esa la dimensión en que los poemas deben ser leídos. La actitud vigilante del personaje encarna la conciencia alerta ante los signos de la contingencia del ser en los fenómenos de la realidad cotidiana. Su presencia desprende un magnetismo que afecta a su entorno, en tanto que su lucidez anticipa en la realidad las señales de la aniquilación. En la construcción del personaje se borran las marcas de la temporalidad, justamente para desvincularlo de toda circunstancia accidental, acrecentando su potencial simbólico. El clarividente sobrenada el espacio de la nieve -el de la inminente aniquilación- y, aunque su canción es dolorosa, parece investido de poderes, su energía traspasa la realidad inmediata.

La nieve, como espacio simbólico, asienta aquí su dominio. Este país del frío es el espacio principal de la ausencia en el poemario; ausente la plenitud de la naturaleza, la pujanza de la vida que se manifiesta en otras estaciones del año, la nieve es la imagen de la muerte cubriendo las supervivencias de una memoria que recupera fragmentariamente imágenes del pasado.

«El vigilante de la nieve» se cierra, igual que el apartado anterior, sobre sí mismo, implicando, otra vez, el origen de la existencia y el retorno a ese mismo origen.

«Aun», adverbio temporal que rotula la tercera parte del libro, abre paso al presente desde el cual el sujeto poético - otra vez en primera persona- se reconoce en un territorio familiar y, a la vez, ajeno. La duración impone a objetos y seres vivos su ley, transformándolos. Para Díez, «Aun, parece centrarse

2 J. M. Diego (1993), «Libro del frío, una mirada caleidoscópica», Diálogo de la lengua, 139. 
en una especie de inventario, de enseñanzas de la edad, de recordación en la que vuelven cosas» ${ }^{3}$. El regreso al momento actual, sin embargo, no es inocuo, puesto que intensifica la impresión de la fugacidad temporal, acentúa la «pureza de los límites». Los recuerdos que persisten son, asimismo, imágenes de la desolación, salvo, quizás, el flujo de palabras que emana del pasado. Un sentimiento de caducidad impregna, como un perfume persistente, la percepción del sujeto acerca de todo cuanto su mirada alcanza. La contingencia individual se asume en la representación del propio yo ante el camino. Este es ahora el espacio donde se instala la ausencia de sentido, el absurdo de un ser que premuere entre el extravío y la soledad de otros seres vivos. Borrosas representaciones urbanas se insertan en el conjunto, abundando en la confusión y la zozobra de un personaje al que perturban imágenes hospitalarias. El sujeto poético aparece acosado por un presente inquietante en el que ensueño y memoria no contribuyen al sosiego, aunque la voz poética mantenga su dictado en un tono sereno.

«Pavana impura» describe la danza de dos cuerpos que han desafiado juntos el paso del tiempo. La pasión amorosa se reviste de un intenso tono melancólico en el anuncio de sus postrimerías. La lucha clásica de Eros y Thanatos adopta en la poesía de Gamoneda una variante que desafía las leyes del tiempo a la vez que enfatiza la brevedad de la vida y de sus goces.

El sábado, día que antecede al domingo o día del Señor, da título al penúltimo apartado en esta versión del Libro del frío. Es, pues, la víspera del encuentro con el misterio de la existencia lo que concentra este bloque poemático. La conciencia de un rostro labrado por los años y por un agua de lluvia que repite sobre la piel el recorrido de las lágrimas -el llanto es un motivo recurrente en este tramo del libro- es la imagen primera de la vejez, continuamente convocada en este espacio -«tapias inmóviles», «balcón del miedo»- que concentra la conciencia de los límites. La palabra densa y esencial del poeta se sitúa entre el abandono de lo que fue y el temor a lo desconocido, cuya inminencia se presiente, recalando en la magnitud progresiva de la pérdida. La pérdida de la infancia, asociada a su vez al abandono y destrucción de los modos de vida rurales en que esta transcurrió; la pérdida del amigo y maestro, del guía visionario que, un día, se anticipó en la partida; la pérdida inherente a la conciencia de caducidad; la pérdida del vigor, la belleza y la plenitud de los cuerpos, etc. enmarcan en Libro del frío un pensamiento que se concentra en torno a la fugacidad del tiempo y que incursiona en la memoria para rescatar fragmentos de una identidad individual en proceso de disolución, imposible ya de restablecer en términos que no incluyan las sucesivas pérdidas. Los versos finales, constituyendo la parte sexta del libro, remiten, como ya dije anteriormente, a un tiempo ya sin tiempo, desde el umbral mismo de lo desconocido, en curso de aproximación hacia ello, pero aún sin alcanzarlo.

La disposición global del libro propicia, simultáneamente, su unicidad y su apertura. Para Miguel Casado «cada fragmento requiere la resonancia de los demás, no se cierra en sí, y la serie de todos ellos funciona con una diversidad y dispersión que tampoco son los del poema largo habitual» ${ }^{4}$. Tal vez la paradójica coherencia del poemario en el seno de esa aparente dispersión guarde relación con la

\footnotetext{
${ }^{3}$ L. A. Díez (2003), «Antonio Gamoneda. Una poesía de la fugacidad (A propósito de Libro del frío)», Paideia, 118.

${ }^{4}$ M. Casado (2001), «Dispersión y poder de lo narrativo», Del caminar sobre el hielo, 123.
} 
120 Tropelías. Revista de Teoría de la Literatura y Literatura Comparada, 21 (2014) María Payeras Grau

observación de Antonio Candau acerca de la relación de la estructura del poemario con los días de la semana, que estarían representadas en sus seis primeras jornadas ${ }^{5}$. La base del poemario, afirmándose en la condición cíclica de la experiencia individual en el tiempo, subrayaría, asimismo, a nuestro juicio, las mermas verificadas por el olvido. Igualmente, la disposición referida a la recurrente repetición de los períodos temporales cuya memoria apuntala la palabra poética, destacaría, por contraste, el silencio que se opera sobre el último día, ese cuyas puertas apenas atraviesa el sujeto poético en la parte sexta, y para el cual la palabra resulta insuficiente. Así, la fragmentariedad del libro, conduciría, desde los silencios pautados por la erosión del tiempo sobre la memoria, hasta el silencio que se materializa ante lo inefable: la ausencia de tiempo.

\section{Referencias bibliográficas}

CANDau, Antonio, «Para una lectura del Libro del frío», Letras Peninsulares, núm. 9 /2-3 (19961997).

CASADO, Miguel, «Prólogo» a A. Gamoneda, Edad, Madrid, Cátedra, 1988.

—, «Dispersión y poder de lo narrativo», Del caminar sobre el hielo, Madrid, Antonio Machado libros, 2001.

DIEGO, José Manuel, «Libro del frío, una mirada caleidoscópica», Diálogo de la lengua, núm. 2 (1993).

DíEZ, Luis Alfonso, «Antonio Gamoneda. Una poesía de la fugacidad (A propósito de Libro del frío)», Paideia, núm. 63 (2003).

\footnotetext{
${ }^{5}$ A. Candau (1996-1997), «Para una lectura del Libro del frío», Letras Peninsulares, 320.
} 